The work described above was carried out as part of the programme of the Metallurgy Section, Division of Aeronautics, Council for Scientific and Industrial Research.

C.S.I.R. Aeronautical Laboratory,

J. B. DANCE

D. J. NORRIS Melbourne. March 5.

'Nelson, H. R., Special Summer Conference on "Friction and Surface Finish", Massachusetts Institute of Technology, June 1940.

Moore, A. J. W., C.S.I.R. Lubrication and Friction Report No. 44 (unpublished).

${ }^{3}$ Wulff, John, Trans. Amer. Inst. Mech. Eng., Iron and Steel Division, 295 (1941).

- Benard, J., Lacombe, S. P., and Chaudron, G., “Journées des Etats de Surface" (Paris, October 1945).

\section{Crystal Structure of Acetanilide: Use of Polarized Infra-Red Radiation}

THE crystal structure of acetanilide has been determined ${ }^{1}$ by classical X-ray diffraction methods, making use of information derived from polarized infra-red radiation technique as a time-saver in the trial-and-error process. The crystals from water or ethanol vary in form from plates $\{100\}$ to truncated bipyramids $\{111\}$, but growth from the molten state results in acicular crystals, elongated along $[b]$ and tabular on (100). The orthorhombic unit cell contains eight molecules and has dimensions:

$[a]=19 \cdot 50,[b]=9.46$ and $[c]=7.96 \mathrm{~A}$. ; space group $P b c a-D_{2} h^{15}$.

Utilizing available data regarding cleavage and optical properties ${ }^{2}$, a three-dimensional molecular model was constructed which was expected to represent the most probable arrangement within the unit cell, and which would normally have been used as a starting-point for preliminary trial-and-error calculations of structure amplitudes. Simultaneously, experiments with polarized infre-red radiation were being conducted by Crooks ${ }^{3}$ which yielded information concerning the directions of the $\mathrm{C}_{6} \mathrm{H}_{5}-\mathrm{N}, \mathrm{N}-\mathrm{H}$, $\mathrm{C}=\mathrm{O}$ and $\mathrm{C}-\mathrm{CH}_{3}$ bonds, as well as indicating the relative orientations of the benzene rings. The rough molecular model was adjusted slightly to take these new data into account, and from the measured atomic parameters, the first thirty or forty structure amplitudes calculated showed remarkably good agreement with the experimental values.

X-ray intensities were obtained from Weissenberg photographs taken about the zero-levels of the [b]and [c]-axes, and from single-crystal oscillation photographs about the [c]-axis. Refinement of the structure was effected by means of Fourier pro-

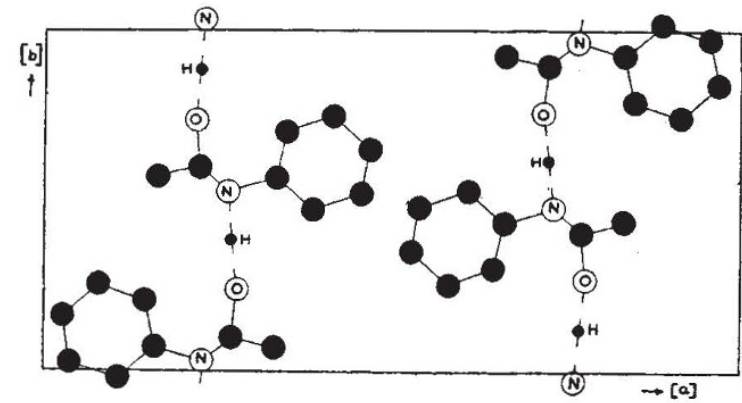

ARRANGEMENT OF MOLECULES IN UNIT CELL BETWEEN $z=0$ AND $z=1 / 2$. THE OTHER FOUR MOLECULES IN THE CELL MAY BE OBTAIN ED BY REFLECTINA THESE FOUR ACROSS THE PLANE $y=1 / 4$ AND GIDDING THEM $c / 2$

jections on (010) and (001) and by means of appropriate lines and sections of a three-dimensional synthesis, with the result that the phases of about three hundred structure amplitudes are now known with certainty. The structure is depicted in the accompanying diagram; bond-lengths appear to be within the accepted values; the length of the hydrogen bond distance $\mathrm{N}-\mathrm{H}-\mathrm{O}$ is $2.9 \pm 0.1 \mathrm{~A}$. It is hoped that further refinement will be carried out later; but since this is by no means certain, the following list of co-ordinates is here placed on record.

\begin{tabular}{|c|c|c|c|}
\hline & $\boldsymbol{X}$ & $\boldsymbol{Y}$ & $\boldsymbol{Z}$ \\
\hline $\mathrm{C}_{2}$ & $0 \cdot 16$ & 0.07 & 0.12 \\
\hline $\mathrm{C}_{2}$ & $0 \cdot 11$ & 0.98 & 0.17 \\
\hline $\mathrm{C}_{3}$ & 0.04 & 0.02 & 0.14 \\
\hline $\mathrm{C}_{4}$ & 0.03 & 0.16 & 0.06 \\
\hline $\mathrm{C}_{8}$ & 0.08 & 0.25 & 0.01 \\
\hline $\mathrm{C}_{\mathrm{s}}$ & 0.15 & 0.21 & 0.04 \\
\hline$N^{\prime}$ & 0.23 & 0.03 & $0 \cdot 15$ \\
\hline $\mathrm{C}_{7}$ & $0 \cdot 27$ & 0.10 & 0.25 \\
\hline$\stackrel{\mathrm{U}}{\mathrm{C}}$ & $\begin{array}{l}0.28 \\
0.33\end{array}$ & $\begin{array}{l}0 \cdot 24 \\
0.07\end{array}$ & $\begin{array}{l}0 \cdot 30 \\
0 \cdot 29\end{array}$ \\
\hline
\end{tabular}

The use of polarized infra-red radiation promises to be of great assistance in erystal structure determ. inations, but further trials with more complex substances will be necessary before a full assessment of its value can be made. It is probable that the infra. red technique will require further development so that small single crystals may be used. In some work with crystals containing water of crystallization it has been found that strong water-bands tend to obscure that part of the spectrum which would yield most information, but it is expected that more complete polarization would enable this difficulty to be overcome. In a crystal where several similar bonds are distributed in different directions, it may not prove possible to analyse the results adequately without a considerable increase in sensitivity of the infrared apparatus.

C. J. Brown

D. E. C. Corbridge

Research Laboratories,

Imperial Chemical Industries, Ltd., Hexagon House,

Manchester 9.

March 22.

${ }^{2}$ Report of Institute of Physics X-Ray Analysis Conference, 1947, J. Sci. Instr., 25, 90 (1948).

Winchell, A. N., "Optical Properties of Organic Compounds" (Wisconsin, 1943).

${ }^{3}$ Crooks, D. A., Nature, 160, 17 (1947).

\section{Structure of Citrinin}

IN view of the recent communication on this topic by Cram ${ }^{1}$ to the editor of the Journal of the American Chemical Society, we wish to record that in the course of an extensive investigation on the chemistry of citrinin initiated in these laboratories in 1945, the synthesis of 4-methyl-5-ethylresorcinol ${ }^{2}$, m.p. of anhydrous material $94-95^{\circ}$, was effected in 1946, and the orientations of the two isomeric phenols ' $A$ ' and ' $B$ ' $\mathrm{C}_{11} \mathrm{H}_{16} \mathrm{O}_{3}$ afterwards established. From these results, inter alia, together with a study of the degradation products of methylated citrinin and of dihydrocitrinin and its ether, evidence has accumulated which leads to the conclusion that citrinin in all probability is best represented by the expression (II).

The claims of competing structures, including those of the quinol (cyclohexadienolone) type, have been considered; but so far as our evidence goes it would seem that formula (II), which is an anhydro 